\title{
LA HISTORIA DE ROMA EN LA FRASEOLOGÍA CASTELLANA*
}

\author{
Antonio Cascón Dorado \\ Univ. Autónoma de Madrid \\ antonio.cascon@uam.es
}

\section{RESUMEN}

Este trabajo estudia las frases coloquiales del español relacionadas con la Historia de Roma. Se analiza su distinta vigencia en la actualidad. Se discute el origen de algunas de ellas y se apuntan posibles causas de su presencia y conservación en nuestra lengua: el influjo de los grandes historiadores romanos, la tradición literaria, el nacionalismo, la homofonía, la ironía y los tópicos de los medios de comunicación.

PALABRAS ClaVE: fraseología, Roma antigua, origen y vigencia

\section{ABSTRACT}

This paper deals with Spanish colloquial phrases related to ancient Rome and its history. The paper analyzes their current degree of vitality in the language and the origin of a number of them. Among some of the reasons proposed for their sustained presence in the language the following outstand: the pervasive influence of the great Roman historians, the literary tradition, nationalism, homophony, irony and clichés in the media.

KEY WORDS: phraseology, ancient Rome, origin and persistence

* Este trabajo se inscribe en el proyecto de investigación HUM 2007-64518/FILO, subvencionado por la Dirección General de Investigación (MEC). 
La Historia de Roma es fuente importante de expresiones populares, prueba evidente de que en otros tiempos eran muchos los hablantes de nuestra lengua que conocían sobradamente los episodios más sobresalientes del auge y la decadencia de aquel famoso Imperio. Sin duda, tal popularidad se debía tanto al interés por conocer acontecimientos de época tan remota como al deleite que los buenos lectores de siglos anteriores encontraban al leer a grandes historiadores clásicos, como Salustio, Livio, Tácito o Plutarco, excelentes narradores que encumbraron el género historiográfico a cimas de calidad y éxito nunca igualados; la historia rivalizaba con la novela ${ }^{1}$ y se leía a estos autores tanto como a Homero, Virgilio o Cicerón. Aunque algunas películas y juegos de ordenador contribuyan en buena medida al conocimiento de las hazañas de los antiguos romanos, la situación es hoy muy distinta. Algunas de estas frases ya no se utilizan, sobre todo entre nuestros jóvenes, y otras han quedado reservadas en exclusiva a la retórica de los eruditos. Sin embargo, encontramos todavía algunas, fuertemente asentadas en el habla corriente, que aluden a aquellos tiempos, sin que, por lo general, quien las emplea conozca el origen y el sentido exacto de la expresión. En las páginas que siguen vamos a hacer un repaso de tales expresiones, fijándonos en su vigencia en la lengua actual, discutiendo el origen de algunas de ellas e intentando averiguar las razones de su pervivencia.

Excluimos las frases que tienen su origen en los usos y costumbres de los romanos antiguos, pero no en su Historia, tales como: «tener muchos humos», «nacer de pie», «tener la negra», «hacerse el sueco», etc., un número importante de dichos, de los que tal vez tengamos ocasión de ocuparnos en otro momento. También dejaremos fuera de este análisis aquellas expresiones que proceden de los Evangelios o la Historia de la Iglesia, que, aunque evocan personajes o episodios que vivieron en el Imperio romano, no forman parte propiamente de la Historia de Roma; nos referimos a expresiones como: «dar al César lo que es del César», «ir de Herodes a Pilatos», «lavarse las manos», «dormir más que los siete durmientes», etc.

Las expresiones que aluden a la Historia de Roma, como es propio en general de la fraseología, se utilizan con un sentido metafórico, equiparando los acontecimientos normales de la vida cotidiana con las grandes empresas de los héroes romanos; por su naturaleza podemos dividirlas en tres grandes grupos:

Las que remiten directamente a episodios relevantes de la Historia de Roma: «hacer pasar a alguien por las horcas caudinas», «conseguir una victoria pírrica», «emprender una defensa numantina», etc.

Las que reproducen, más o menos alteradas, frases pronunciadas por grandes personajes en momentos críticos: «llegué, vi, venci» (Julio César), «hay que saber morir de pie» (Vespasiano), «iqué artista muere conmigo!» (Nerón), etc.

Aquellas que evocan un personaje famoso como arquetipo de un tipo de conducta humana: «ser un Mecenas», «ser un Séneca», «comer como un Heliogábalo», etc.

${ }^{1}$ Cf. Antonio Cascón (2006): «Novela histórica e historiografía clásica», Relat, 6, 2006, 217-238. 


\section{Vigencia en la lengua actual}

\subsection{Expresiones en desuso}

Hay frases, con toda certeza vinculadas a la Historia de Roma, que desgraciadamente han desaparecido casi por completo del español actual. Hoy resulta raro oír que alguien está en el Aventino para indicar su enfado con los demás; de hecho, la expresión no aparece en ninguno de los repertorios fraseológicos que he consultado, aunque la oía en mi infancia en boca de personas de escasa cultura. La frase evoca la retirada a esa colina de la plebe romana para presionar en demanda de más derechos frente a los patricios. Se trata del primer episodio de la llamada lucha entre patricios y plebeyos, cuando en el año 494 a. C., poco después de la instauración de la República, los plebeyos decidieron retirarse de la Ciudad y ocupar la colina del Aventino, conocida también como Mons Sacrum. Para conseguir la igualdad completa con los patricios, los plebeyos tuvieron que retirarse en más ocasiones al Aventino, al menos tres a lo largo del siglo V, aunque en otros momentos bastó con la amenaza de retirada. La Historia de Roma llegó a ser tan conocida que «marcharse al Aventino» se empleó con hispánica guasa para designar a aquel que se enfada, o mejor se mosquea, que es el término comúnmente empleado en el español coloquial.

En mi entorno familiar se emplea bastante la expresión «comer como un Heliogábalo», pero resulta desconocida para muchas de las personas a las que he consultado, aunque aparece comentada en el repertorio fraseológico de Calles-Bermejo ${ }^{2}$. Nuestra cultura popular eligió a este emperador romano de principios de siglo III como comilón prototípico a partir de lo que de él nos cuentan sus biógrafos. En cuanto a la glotonería que le ha llevado a nuestra fraseología, Elio Lampridio refiere en numerosos lugares su pasión por la comida, diciendo que superaba a Apicio y a Vitelio ${ }^{3}$ y describiendo con detalle algunos de sus sibaríticos banquetes y los platos que en ellos se servían: «hizo servir en una sola comida las cabezas de seiscientos avestruces, para que se comieran los sesos. Ofreció una vez un banquete tan espléndido que sirvieron veintidós platos con grandes cantidades de manjares» ${ }^{4}$. Hay, como éstos, otros pasajes ${ }^{5}$ que, como dice el propio Lampridio, también tenían la intención de desprestigiar a Heliogábalo ${ }^{6}$.

Revisando los diferentes diccionarios y repertorios fraseológicos, he encontrado otras expresiones curiosas o interesantes, que nunca antes había oído. Martín Sánchez ${ }^{7}$ recoge la expresión «ninfa Egeria», que es utilizada para referirse a aquella persona que impulsa las acciones de otra de manera sigilosa; sobre todo se aplica a las mujeres que gobiernan con mano izquierda a sus maridos. La frase tiene su origen en la ninfa de tal nombre, que, según refieren Livio, Dionisio de Halicarnaso y Plutarco, dictaba al segundo rey de Roma, Numa Pompilio, sus actos de gobierno. En opinión de Livio, sus consultas con la ninfa eran una argucia política para infundir al pueblo el temor de los dioses, «ele-

\footnotetext{
2 José Calles y Belén Bermejo (2006): Dichos y frases hechas, Madrid, Libsa, 2006, p. 20.

${ }^{3}$ Cf. Scriptores Historiae Augustae, Antoninus Heliogabalus, 24, 4.

${ }^{4}$ Ibidem, 30,3. Traducción de Vicente Picón-Antonio Cascón (1989), Madrid, Akal.

5 Ibidem, 20, 4; 21, 33...

6 Ibidem, 30,8.

7 Cf. Manuel Martín Sánchez (1997): Diccionario del español coloquial, Madrid, Tellus, p. 250.
} 
mento de la mayor eficacia para una masa ignorante y en bruto por entonces». Lo que no está claro es si Numa contrajo o no nupcias con la ninfa, hecho que afirma Plutarco, pero no Livio ni Dionisio ${ }^{8}$.

El dicho «ser arrojado por la roca Tarpeya», que, según Calles-Bermejo ${ }^{9}$, se utiliza para referirse al que cae en desgracia, nos lleva aún más lejos en el tiempo. Tarpeya era una doncella romana, que, según la leyenda, traicionó a los romanos cuando, en tiempos de Rómulo, los sabinos a las órdenes de Tito Tacio, pretendían entrar en el Capitolio. Deslumbrada por los brazaletes de oro que éstos llevaban en sus brazos, les facilitó la entrada a cambio de que le entregaran «lo que llevaban en su brazo izquierdo». Una vez franqueada la muralla, Tacio ordenó a sus soldados que, junto con los brazaletes, arrojaran sobre Tarpeya los pesados escudos que llevaban en el brazo izquierdo. La muchacha fue aplastada y dio nombre a la roca en que murió ${ }^{10}$. Desde allí, según recuerda Plutarco, solía arrojarse en Roma a los condenados a muerte: «sólo ha quedado una roca, a la que aún ahora llaman Tarpeya, de la que son precipitados los malhechores».

J. M. Iribarren ${ }^{11}$ trasmite otro dicho de utilización muy restringida: «Luculo come en casa de Luculo». Se refiere a Lucio Licinio Luculo, general romano que obtuvo en su tiempo una notable gloria militar por sus triunfos en Asia y Armenia y cuyo renombre ha llegado hasta nosotros gracias, sobre todo, a la pluma de Plutarco, quien en sus Vidas paralelas confronta su biografía con la del griego Cimón. Este patricio romano venció a Mitrídates del Ponto y realizó exitosas incursiones en Partia (73-67 a. C.), pero fue víctima de las intrigas políticas en su propia patria. Luculo, escéptico o asqueado, decidió pasar el resto de sus días regalándose y regalando a los demás con el producto del cuantioso botín obtenido en sus victorias asiáticas. Entre las anécdotas que salpican el relato plutarqueo, todas ellas de recomendada lectura, una se hizo tan conocida como para forjar la expresión coloquial que venimos comentando. Luculo gustaba rodearse de hombres de letras a los que agasajaba con sus banquetes; en su casa era raro el día que no había invitados...Pero dejemos que sea Plutarco quien cuente la anécdota:

Cenaba un día solo y no se le puso sino una mesa y una cena moderada; se incomodó por ello e hizo llamar al criado que se ocupaba de estas cosas; y como éste le respondiese que no habiendo ningún convidado creyó no querría una cena más abundante: «¡Pues cómo! —le dijo- ¿No sabías que hoy Luculo tenía a cenar a Luculo? ${ }^{12}$

De aquí procede nuestro «hoy Luculo come con Luculo», que suele emplearse cuando alguien se homenajea a sí mismo, en sentido real o figurado, sin necesidad de otros pretextos. La anécdota fue recogida por Fray Antonio de Guevara en su Menosprecio de corte y alabanza de aldea ${ }^{13} \mathrm{y}$, sin duda, contribuyó a que la expresión calara en el habla popular.

${ }^{8}$ Cf. Livio, I 19-21; Dionisio de Halicarnaso, II 60-61; Plutarco, Numa, 4.

9 Op. cit., p. 75.

${ }^{10}$ Este es un resumen de la versión más extendida de la leyenda, aunque hay otras que incluso libran de culpabilidad a la muchacha. Cf. Livio, I 11, 7-9. Dionisio de H., II 38-40 y Plutarco, Rómulo, 17, 2.

11 José María Iribarren (1994): El por qué de los dichos, Pamplona, Dpto. de Educación y Cultura, p. 225.

12 Plutarco, Luculo, XLI 1.

13 Cf. cap. XVII. 


\subsection{Expresiones que no suelen relacionarse con la antigua Roma}

Contrariamente a lo que acabamos de comentar, hay otros dichos, de uso muy frecuente, que tienen su origen en la Historia de Roma y que, sin embargo, no suelen vincularse con ella. Veámoslos:

La frase «más vale tarde que nunca», que, según el Diccionario de Autoridades ${ }^{14}$, «significa que no debe desanimar para emprender alguna cosa el haber empezado tarde a executarla» es traducción del latín potius sero quam numquam, probablemente una genialidad de Tito Livio, que se convirtió en frase hecha ya en latín clásico y, como tal, ha pasado a las lenguas modernas. La expresión se enmarca, como «estar en el Aventino», en la lucha entre patricios y plebeyos, cuando en el año 445 los cónsules patricios Genucio y Curiacio se opusieron a las propuestas de ley del tribuno de la plebe Canuleyo, afirmando que la República patricia debía reaccionar, pues potiusque sero quam numquam obviam eundum audaciae temeritati ${ }^{15}$. Los refraneros latinos de Herrero Llorente, Cantera y E. Valent $1^{16}$ recogen el proverbio y citan el pasaje de Livio, aunque sin comentarlo. Sin embargo, Iribarren ${ }^{17}$, citando a Bastús ${ }^{18}$, apunta un origen distinto, aunque también clásico. Según estos autores la frase procedería del filósofo Diógenes, quien, deseando aprender música a una edad avanzada e increpado por alguien que le reprochó su edad tardía para aprender, contestó: Praestantius sero doctum esse quam numquam. A mi juicio, parece claro que el origen de la frase está en la Historia de Livio y no en Diógenes, pues las palabras de éste no son un calco de la expresión y aquellas sí. No podemos descartar, sin embargo, que el dicho existiera ya en griego y que Livio se limitara a llevarlo a su narración.

La expresión «eso lo ve hasta un ciego» también parece tener su origen en un episodio de la Historia de Roma que nos cuenta Tito Livio ${ }^{19}$. Durante la llamada Segunda Guerra Macedónica, el rey Filipo V entabló conversaciones de paz con el comandante romano Tito Quincio Flaminino que no llegaron a buen puerto. Era el año 197. Flaminino estaba acompañado por Alejandro y Feneas, representantes de los etolios, que reprocharon al rey su actitud imperialista. La réplica del rey fue violentamente interrumpida por Feneas, que, envalentonado ante la presencia de su aliado romano, señaló que no era tiempo de hablar sino de luchar o de plegarse a las condiciones impuestas por el que es superior. Filipo, ironizando con una afección de la vista del tal Fineas, añadió: Apparet id quidem etiam caeco, pues, según comenta Livio, el tal Filipo era hombre ingenioso y mordaz que «ni siquiera en los momentos graves controlaba el humor». Como en el caso anterior, no sabemos si el dicho ya existía, en latín o en griego, o si surgió de la anécdota narrada por Livio. En cualquier caso, parece seguro que la frase se convirtió en proverbio ya en la antigua Roma, pues, aunque no la he visto en los libros de refranes lati-

${ }^{14}$ Diccionario de Autoridades (1969): Madrid, Gredos.

15 Cf. Livio, 4, 2,11.

${ }^{16}$ Víctor José Herrero (1980): Diccionario de expresiones y frases latinas, Madrid, Gredos, p. 183. Jesús Cantera (2005): Refranero Latino, Madrid, Akal, p. 179. Eduardo Valentí (2004): Aure dicta. Dichos y proverbios del Mundo Clásico, Barcelona, Crítica, p. 43.

17 Op. cit., pág. 303.

18 Joaquín Bastús (1855): Memorándum anual y perpetuo, Barcelona, tomo $1^{\circ}$, p. 558.

19 Cf. Tito Livio, XXXII 34, 1-3. 
nos, Quintiliano, en un pasaje de su obra en la que defiende la gratuidad de las artes liberales y la conveniencia de no comerciar, concluye con una variante de la frase de Livio: caecis hoc, ut aiunt, satis clarum est ${ }^{20}$.

Parece remontarse a Cicerón la expresión «el pensamiento es libre», que suele emplearse en contextos relacionados con la utopía, pues una cosa es imaginar y soñar y otra muy distinta llevar las ideas a la práctica. En el discurso en defensa del político Anio Milón, acusado de haber matado a Publio Clodio, Cicerón, empeñado en demostrar que la muerte de Clodio había sido sumamente saludable para el Estado, pide a los jueces que imaginen que la condena de Milón pudiera devolver la vida a Clodio, «pues», dice el orador, «nuestra mente es libre y ve lo que quiere» ${ }^{21}$; esa visión, continúa el orador, les aterrorizaría, porque ellos saben que Clodio era un peligro para la República. Esta afortunada frase de Cicerón, liberae sunt enim nostrae cogitationes, que interesadamente pretendía hacer que los jueces volvieran su pensamiento a lo que no era políticamente correcto, fue retomada por otros insignes romanos, como Ulpiano o San Ambrosio ${ }^{22}$ y, bastantes siglos después, por W. Shakespeare, quien introdujo la frase («thought is free») en su obra La tempestad ${ }^{23}$. Con estos apoyos importantes de la tradición, la frase ha llegado hasta nuestros días y se utiliza no sólo en nuestra lengua sino también en otras de nuestro entorno.

\subsection{Algunas expresiones dudosas}

En mi revisión de los repertorios y diccionarios fraseológicos de la lengua castellana he echado en falta el comentario de dos dichos populares que, creo, pueden estar relacionados con la Historia de Roma.

El primero de ellos tiene escaso uso en la actualidad, pero fue muy utilizado en otras épocas. Me refiero a «tener odios africanos», que se emplea para subrayar el odio profundo entre personas o grupos. Creo que el «odio africano» más famoso es el de la familia cartaginesa de los Barca hacia los romanos, que, según Nepote, Amílcar dejó en herencia a su hijo Aníbal y éste conservó hasta su muerte ${ }^{24}$. Otros historiadores romanos, como Fabio Píctor o Tito Livio, convirtieron ese odio en causa de la Segunda Guerra Púnica, aludiendo con reiteración a la famosa perfidia punica ${ }^{25}$. La Tercera Guerra Púnica, que no es en realidad otra cosa que el asedio y destrucción de Cartago (146 a. C.), fue promovida y alentada desde Roma por Catón el Censor y sus aliados políticos, quienes sostenían que Roma nunca estaría segura mientras tuviera en la costa africana un enemigo tan poderoso. Para que los brutales designios de Catón y Escipión Emiliano pudieran cumplirse, la propaganda contra la perfidia púnica y su odio a Roma tuvo que ser de nuevo convenientemente agitada. Los «odios africanos» cobraron un nuevo impulso cuando el númida Yugurta hizo la guerra a Roma, invadiendo la provincia de África que

${ }^{20}$ Quintiliano, XII 7, 9.

21 Cicerón, Pro Milone, 29,79.

${ }^{22}$ Cf. Ulpiano, Dlg. 48, 19, 18 y Ambrosio, De virginit., 17, 107.

23 Acto III, Escena 2. (canción de Estéfano).

${ }^{24}$ Cf. Nepote, Aníbal, 1, 3. «Éste conservó, como por herencia, el odio paterno hacia los romanos que le había legado su padre con tanta convicción que antes renunció a su vida que a éste». 
había sido creada tras la destrucción de Cartago. También Yugurta odiaba a los romanos y no dejó de guerrear contra ellos hasta ser capturado; fue una guerra bastante duradera (107-117) y en ella los ejércitos romanos sufrieron algunos reveses importantes. Así que el odio de los africanos, púnicos o númidas, iba adquiriendo tintes proverbiales. Quizá por eso en la Historia Augusta encontramos, en sintonía con Livio y en diversos pasajes, distintas referencias a la escasa lealtad de los africanos, permanentemente dispuestos a la traición ${ }^{26}$.

También me parece muy probable que la expresión «subirse a las barbas» pueda tener su origen en uno de los episodios acaecidos durante la toma de Roma por los galos. Es una de esas leyendas creadas para dignificar el papel de los romanos en tan deshonrosa derrota, pues antes de la conquista de la Ciudad los senones de Breno les infligieron una humillante derrota en la batalla del río Alia, en la que los soldados huyeron del frente en desbandada, en un gesto tan vergonzoso como infrecuente en la historia del ejército romano. Cuenta Plutarco que, tras la huida de los soldados, Roma quedó abandonada a su suerte. De sus habitantes, los más jóvenes y con capacidad para combatir se refugiaron con Manlio en el Capitolio y algunos huyeron buscando refugio en ciudades vecinas; sin embargo, los senadores y algunos sacerdotes decidieron aguardar, sentados en sus sitiales de marfil y vestidos con sus vestimentas oficiales, la llegada de los galos, lo que no ocurrió hasta el tercer día después de la batalla del Alia:

Breno, bajando a la plaza, se quedó asombrado de ver aquellos hombres sentados con aquel adorno y tan silenciosos y, sobre todo, de que marchando hacia ellos los enemigos, no se levantaron ni cambiaron el semblante...Era, pues, para los galos un espectáculo extraño, así que largo rato estuvieron dudosos sin osar acercarse, ni pasar delante, teniéndolos por hombres de otra especie superior; pero después que uno de ellos, más resuelto, se atrevió a acercarse a Manio Papirio y alargando la mano le cogió y mesó la barba, que la tenía muy larga, y Papirio con el báculo le sacudió e hirió en la cabeza, sacando el bárbaro su espada, lo mató. En seguida, cargando sobre todos los demás, les dieron muerte ${ }^{27}$.

Tal vez de aquel senón que «se subió a las barbas» de Papirio proceda nuestro dicho, pues en aquellos tiempos se consideraba un agravio tocar la barba de los ancianos, costumbre que pasó después a los países romanizados, como demuestra el famoso verso de Mío Cid: «por aquesta la mi barba que nadi non la mesó» ${ }^{28}$.

Sin embargo, hay otros dos dichos que, a mi juicio, se vinculan erróneamente con la Historia de Roma, aunque tal vez me equivoque. J. M. Iribarren ${ }^{29}$, al comentar la expresión «negro como Tito», apunta, entre otras, la posibilidad de que su origen esté en el se-

${ }^{25}$ Cf. El famoso retrato de Aníbal. Livio, XXI 4, 9: Has tantas viri virtudes ingentia vitia aequabant: inhumana crudelitas, perfidia plus quam Punica, nihil veri, nihil sancti, nullus deum metus, nullum ius iurandum, nulla religio.

${ }^{26}$ Cf. Julio Capitolino, Los tres gordianos, 15, 2: «Tan pronto como fue destituido, Capeliano reunió a los moros entorno a él y con una tropa tumultuaria se dirigió a Cartago, donde el pueblo con su acostumbrada lealtad púnica, se inclinó hacia él». Ibidem, 16, 3: «Gordiano, al darse cuenta de que... no podía confiar en la lealtad púnica...decidió poner fin a su vida, ahorcándose él mismo».

${ }^{27}$ Cf. Plutarco, Camilo, 22, 5-6.

${ }_{28}$ Cf. Ms. Per Abad, 1355, v.2832.

${ }^{29}$ Op. cit., p. 186. 
gundo emperador de la dinastía Flavia. J. Calles y B. Bermejo ${ }^{30}$ comentan también esta hipótesis, basada en una noticia cuya fuente desconozco - desde luego Suetonio nada dice- que aludiría a la tez morena que teñía al emperador después de su larga estancia en la provincia de Judea. Sin embargo, estos mismos autores se hacen eco de la opinión más extendida, que considera más correcta la forma «estar negro como un tito», con la palabra en minúscula, en alusión a los guisantes secos y renegridos, que popularmente llamamos titos.

También se defiende que la expresión «poner las manos en el fuego» tiene su origen en el episodio legendario de Mucio Escévola, cuando aquel héroe romano colocó su diestra en un brasero cercano para indicar a Porsena y sus soldados que las torturas no le harían confesar los planes de sus conciudadanos. Parece, sin embargo, más acertado suponer, tal como indica el Diccionario de Autoridades, que la expresión derive de los llamados «juicios de Dios». Una práctica inquisitorial que se aplicaba, sobre todo, a las mujeres acusadas de adulterio, quienes tenían que poner su mano en el fuego para demostrar su inocencia; si la quemadura no sanaba en el plazo de tres días, eran enviadas a la hoguera. Se entendía que, a través de la curación o no de la acusada, la divinidad declaraba la verdad ${ }^{31}$.

\subsection{Dos frases mal interpretadas}

De todas las frases atribuidas a Nerón que nos han trasmitido sus biógrafos, una se ha hecho famosa en nuestra lengua y también en otras y la repetimos en contextos distintos para burlarnos del artista pagado de sí mismo. Me estoy refiriendo a la que pronunció justo antes de morir, qualis artifex pereo!, recogida por Suetonio y Dión Casio, y que normalmente traducimos por «iqué artista muere conmigo!», como trasunto del personaje hinchado de vanidad que a las puertas de la muerte mantiene su paranoico engreimiento. Edward Champlin ${ }^{32}$ se refiere a la frase que estamos comentando en su reciente monografía sobre el polémico emperador, demostrando, a mi juicio convincentemente, que ha sido secularmente mal traducida. Cuando los acompañantes de Nerón le instan a acabar con su vida para sustraerse a los ultrajes que le esperaban si era capturado vivo por sus perseguidores, el emperador les pidió que abriesen un foso a su medida y que lo rodeasen con algunos pedazos de mármol: «a cada orden que daba se ponía a llorar y repetía sin cesar: qualis artifex pereo!» ${ }^{33}$. Champlin muestra cómo en el contexto de la frase -Nerón indica a sus acompañantes la forma que debe tener su nicho-, el latín artifex debería traducirse por «artesano», tal como indica el griego technites que emplea Dión Casio ${ }^{34}$. De manera que la expresión debería traducirse por «iQué artesano soy en mi agonía!», con el sentido contrario al que normalmente damos a la frase, pues Nerón lamenta haber caído tan bajo como para tener que hacer labores artesanales en el momento de su muerte.

\footnotetext{
30 Op. cit., p. 57.

31 Cf. Manuel Martín Sánchez, op. cit., p. 222 y José Luis García Remiro (2001): ¿Qué queremos decir cuando decimos...?. Frases y dichos del lenguaje diario, Madrid, Alianza, p. 177-178.

${ }^{32}$ Cf. E. Champlin (2006), Nerón, Madrid, Turner, pp. 68-69.

${ }^{33}$ Cf. Suetonio, Nerón, 49, 1.

34 Cf. Dión Casio, 63, 29, 2.
} 
En mi opinión, la frase: la mujer de César no sólo tiene que ser casta sino también parecerlo es, como la anterior, producto de una interpretación interesadamente equivocada. En realidad, no fueron éstas las palabras exactas de Julio César ni éste quiso decir lo que normalmente interpretamos con ellas. César se casó cuatro veces y sus matrimonios estuvieron casi siempre motivados por cuestiones de política familiar. Como es sabido, en esta época los matrimonios eran de conveniencia y tenían como objetivo fortalecer la posición social de las familias de los contrayentes. Cosa distinta eran los amores e incluso los amoríos. Es conocido que César era un gran libertino, exponente de la bisexualidad propia de la época, pero entre sus coetáneos era normal casarse varias veces. En materia sexual, las costumbres de aquella época poco tenían que ver con las nuestras. El adulterio estaba a la orden del día y, aunque en la sociedad machista romana las mujeres tuvieran que tener algún miramiento, la censura social era muy leve; el comportamiento desenfrenado de una mujer podía ofender más al pater familias que al marido, que comúnmente no se casaba por amor. En cualquier caso, está claro que ni César ni Craso ni Pompeyo padecían el «síndrome del cornudo», durante mucho tiempo y todavía vigente en la sociedad occidental. Siendo esto así, debemos entender que Julio César no pronunció la frase que venimos comentando con el sentido que normalmente le damos. Paul Veyne ${ }^{35}$, buen conocedor de estos temas, dice que se trató en realidad de un esnobismo de César, el capricho del aristócrata elegante. A mí me parece, sin embargo, que detrás de esta frase sólo hay motivos políticos. Pero vayamos al contexto:

Cuentan Plutarco y Suetonio que César repudió a Pompeya ante la sospecha de que hubiera tenido relaciones adúlteras con Publio Clodio, el famoso tribuno de la plebe, cuando éste, disfrazado de mujer, se introdujo sacrílegamente en las celebraciones de la Bona Dea, una fiesta religiosa sólo reservada a las mujeres. Este acto sacrílego le costó a Clodio una acusación formal ante los jueces; entonces, César fue llamado a declarar y el acusador, para demostrar que el sacrilegio había sido cometido por Clodio, le preguntó por las razones del repudio de su esposa; César contestó que no sabía nada. El acusador insistió, inquiriendo nuevamente por las razones del repudio. Entonces fue cuando dijo: «Es necesario que los míos estén tan exentos de sospecha como de crimen».

Pero, naturalmente, el crimen de Pompeya no fue el adulterio con Clodio sino el haberlo practicado en una fiesta religiosa, en la que tales prácticas quedaban excluidas. La acusación contra Clodio fue un escándalo político, orquestado sin duda por sus rivales, y César quería verse libre de toda sospecha; nada había tenido que ver en la presunta trasgresión de un rito religioso. Con toda probabilidad las relaciones adulterinas entre Clodio y Pompeya existieron, incluso en aquella fiesta, al menos así lo afirmaron la madre y la hermana de César ${ }^{36}$, pero para éste y para la sociedad romana esto era lo de menos; lo que importaba era el dónde, no el qué. Cuando César dice que ante la más mínima sospecha había repudiado a su mujer, lo que quiere decir es que él es un buen ciudadano y un buen político, respetuoso con las instituciones religiosas, y que nada tiene que ver en un asunto de tal clase. Por lo demás, como puede verse, nada le importó

35 Paul Veyne (1990): La sociedad romana, Madrid, Mondadori, p. 178 (traducción de Pilar González).

${ }^{36}$ Cf. Suetonio, César, 74, 2: «declaró que él no se había enterado de nada, aunque su madre Aurelia y su hermana Julia habían referido todos los detalles fielmente a los jueces». (Trad. de V. Picón, Madrid, Cátedra, 1998). 
testificar a favor de Clodio, con quien no tenía asuntos personales pendientes y, sin embargo, mantenía una relación política muy útil para su carrera ${ }^{37}$.

Augusto fue el primero en dictar leyes contra el adulterio y, aunque otros emperadores tuvieron que reformarlas y agravar las penas, la mentalidad social fue cambiando paulatinamente, sobre todo por el influjo del estoicismo. Antes del triunfo del cristianismo, encontramos ya textos en favor de la perdurabilidad del matrimonio y de la castidad, que se empieza a considerar una virtud ${ }^{38}$.

Plutarco y Suetonio dicen que la acusación contra Clodio fue por impiedad o sacrilegio, aunque a veces aluden al adulterio ${ }^{39}$. Hay que tener en cuenta que ambos autores escriben siglo y medio y dos siglos después de que estos hechos hubieran ocurrido, y para entonces las cosas habían cambiado en gran medida y todavía habrían de cambiar más. Los dos biógrafos tienen en este tema una perspectiva distinta a la de los coetáneos de César, pero, si la frase se expresa con el sentido que le damos en nuestra lengua, haciendo alusión a la necesidad imprescindible para el varón de que su mujer esté libre no sólo de culpa sino de sospecha, es porque en tiempos posteriores fue calando la idea de que nada había más horrible para el marido que la traición de su mujer. Sin embargo, César no dijo la frase con tal intención.

\section{UN PEQUEÑO RECUENTO}

Si excluimos «poner la mano en el fuego» $\mathrm{y}$ «más negro que un tito» y aceptamos «subirse a las barbas» $\mathrm{y}$ «tener odios africanos», podemos contabilizar, aunque pueda haber alguno más, 35 dichos relacionados con la Historia de Roma, cuya vigencia en el español actual es, como estamos viendo, muy desigual. Tras algunas encuestas informales con alumnos y compañeros, he podido establecer un balance aproximado como el siguiente:

La mayoría tienen un uso frecuente, al menos 14 ejemplos: «más vale tarde que nunca», «subirse a las barbas», «es una victoria pírrica», «eso lo ve hasta un ciego», «saber dónde le aprieta a uno el zapato», «la mujer de César no sólo tiene que serlo...» «hacer una defensa numantina», «ser o estar proscrito», «soltar una filípica a otro», «la suerte está echada», «llegué, vi, vencí», «ser un Mecenas», «brillar por su ausencia», «saber morir de pie».

${ }^{37}$ Cf. Plutarco, César, 10, 8-10: «César repudió en seguida a Pompeya, y, cuando fue citado al juicio como testigo, declaró no conocer ninguna de las imputaciones expresadas contra Clodio. Y cuando, ante el carácter sorprendente de esta declaración, el acusador le preguntó: «¿Entonces, cómo es que has repudiado a tu mujer?», respondió: «Porque estimé que la que sea mi mujer ni siquiera debe ser objeto de sospechas». Esta contestación, unos dicen que César la dio porque así es como pensaba, y otros, que por congraciarse con la plebe, decidida firmemente a salvar a Clodio». (Trad. de E. Crespo, Barcelona, Bruguera, 1983).

${ }^{38}$ Cf. P. Veyne, op. cit., p. 187. Recordemos, por ejemplo, que Marco Aurelio se enorgullecía de no haber tocado a sus criados Benedicta y Teódoto (Meditaciones, I 17).

${ }^{39}$ Cf. Suetonio, César, 6,2: «pero después se divorció de ella pensando que había sido arrastrada al adulterio por P. Clodio, pues era tan persistente el rumor de que éste había entrado a verla vestido de mujer durante la celebración de unas fiestas públicas, que el senado decretó una investigación judicial sobre un delito de profanación de ritos sagrados». (Trad. de V. Picón, Madrid, Cátedra, 1998). 
Otras son conocidas de las personas de cierta edad y cultura, aunque su uso es cada vez menos frecuente, sobre todo entre los jóvenes. En total, otros 11 ejemplos: «iay de los vencidos!», «tener odios africanos», «éstas son las delicias de Capua», «Roma no paga traidores», «el pensamiento es libre», «pasar el Rubicón», «vivir una paz Octaviana», «se armó un Tiberio», «ser un Séneca», «qué artista muere conmigo», «pasar por las horcas caudinas».

Finalmente, otras, a pesar de su notable interés, parecen, si no haber desparecido, sí estar en franco retroceso: «estar en el Aventino», «tener hambre calagurritana», «ser arrojado por la roca Tarpeya», «tener su Ninfa Egeria», «Luculo come en casa de Luculo», «largar una catilinaria», «esto no huele», «amigos he perdido el día», «comer como un Heliogábalo», «el cadáver de un enemigo siempre huele bien».

Probablemente, en otras épocas la utilización de estas expresiones pudo ser un signo de distinción, una especie de código que permitía al hablante medir el nivel cultural de su interlocutor. Hoy podríamos decir que tal aspecto se ha perdido y que el uso de estos dichos con tales fines sería calificado de pedantería. Es curioso comprobar cómo entre las expresiones que consideramos más utilizadas sólo encontramos dos nombres propios: César y Mecenas; el primero se ha conservado porque su gloria histórica le ha proporcionado un conocimiento universal, el segundo, en realidad, no es un nombre propio, pues mecenas aparece ya en nuestros diccionarios con el significado de «patrono de las artes». Han caído en el desuso casi todas las expresiones que contenían una referencia concreta a un personaje o lugar cuya correcta pronunciación exige un mayor conocimiento de la anécdota histórica a la que se refiere: Egeria, Tarpeya, Aventino, Heliogábalo, Calagurris, Luculo, Catilina; otras se mantienen a duras penas: Horcas caudinas, Tiberio, Octavio, etc.

\section{CAUSAS DE LA PRESENCIA Y CONSERVACión DE ESTOS DiCHOS EN LA LENGUA COLOQUIAL}

Naturalmente, no es éste el lugar para comentar con el detenimiento que quizá merezcan cada una de las frases que hemos citado más arriba ${ }^{40}$, pero, como puede verse, aluden a episodios y personajes de todas las épocas de la Historia de Roma: 2 se refieren a la fase monárquica, 23 a la republicana y sólo 10 a la imperial. Quizá lo más llamativo es ese evidente predominio de la época de la República, que no está en consonancia con el «éxito» que goza en nuestros días la época imperial. La mayoría de las numerosas películas y novelas históricas de romanos se ocupan con preferencia de los emperadores y sus circunstancias, olvidando los interesantes avatares de los grandes generales y políticos de la República. En la actualidad, sólo la última etapa republicana parece poder competir en popularidad con Augusto, Calígula, Nerón, etc., emperadores cuyas vidas y milagros son demandados con particular curiosidad por lectores y espectadores. Está claro, tal como decíamos al comienzo, que en los siglos precedentes las cosas no fueron así. Los lectores evidentemente preferían la etapa republicana, o deberíamos quizá decir a los escritores que nos trasmitieron ese momento histórico.

40 Alguna de ellas se comentan en Antonio Cascón (1994), «De las «arcas claudinas» a la puta por rastrojo», Quid vltra faciam (L. Macía et alii eds.), Madrid, Eds. de la UAM, 1994, pp. 216-223. 


\subsection{Los grandes historiadores}

Sin duda, el pintoresquismo de muchos episodios de la Historia de la República constituye la primera causa de la presencia de estos dichos en nuestra lengua, pero es necesario destacar como se merecen las dotes narrativas y el poderoso influjo en nuestras letras de historiadores como Plutarco, Livio y Suetonio, sin cuyas obras muchas de estas expresiones no habrían alcanzado tal grado de popularidad.

Probablemente, ese predominio de la época republicana esté relacionado con las anécdotas transmitidas en las Vidas Paralelas. La pluma de Plutarco puede estar detrás de muchas de las expresiones antes citadas. Es seguro que «saber donde le aprieta a uno el zapato» tiene su origen en una anécdota que nos transmite en la Vida de Emilio Paulo, e igualmente «Luculo come en casa de Luculo» sólo puede proceder de la anécdota, comentada más arriba, que aparece en la Vida de Luculo. Parece claro también que su ameno relato de las victorias de Pirro contra los romanos es responsable del dicho «es una victoria pírrica», pues las otras fuentes que nos hablan de Pirro son secundarias. Sin duda, su espléndida narración de las proscripciones de Sila ha influido decisivamente para que «ser un proscrito» entrara en nuestra lengua coloquial. Las frases de Julio César que se han convertido en dichos también parecen proceder de la Vida plutarquea («La suerte está echada», «La mujer de César no sólo tiene que serlo» y «Llegué, vi y vencí»), aunque también se encuentran en la biografía de Suetonio, medio siglo posterior al de Queronea.

La responsabilidad de la presencia en nuestra lengua de otras cuatro expresiones («ser arrojado por la roca Tarpeya», «tener su Ninfa Egeria», «subirse a las barbas» y «iAy de los vencidos!») hay que repartirla entre Plutarco y Livio, siendo imposible decir cuál de los dos ha podido tener más influencia, pues sus obras parecen haber alcanzado una difusión similar en nuestro país. De hecho, además de estas cuatro, hay otras seis que, sin duda, tienen su origen en magníficos pasajes de $A b$ urbe condita: «estar en el Aventino», «pasar por las horcas caudinas», «tener odios africanos», «estar en las delicias de Capua», «eso lo ve hasta un ciego» y «más vale tarde que nunca».

Antes hemos mencionado a Suetonio, a quien es justo otorgar la mayor responsabilidad en los dichos de época imperial. Él nos ha trasmitido «qué artista muere conmigo», «saber morir de pie», «esto no huele», «amigos he perdido el día» y «el cadáver de un enemigo siempre huele bien» $y$, sin duda, tiene una importante responsabilidad en la presencia de otros como «paz Octaviana» $\mathrm{o}$ «se armó un Tiberio».

\subsection{La tradición literaria}

Aunque hay otros autores importantes, como Cicerón o Tácito, Livio, Plutarco y Suetonio son, como acabamos de decir, los que más han contribuido a mantener en nuestra fraseología el recuerdo de la Historia de Roma. Aún está por hacer un estudio global que valore el influjo de cada uno de ellos en la educación y las letras españolas, aunque en el caso de Plutarco hay mucho avanzado con los trabajos de A. Pérez Jiménez 
y J. Bergua ${ }^{41}$. Los artículos de R. Delicado ${ }^{42}$ sobre Livio y los esbozos de V. Picón ${ }^{43}$ sobre Suetonio marcan también una buena dirección para investigaciones futuras sobre ambos autores latinos.

Es evidente que, sin el apoyo de la tradición posterior, estas expresiones no habrían llegado hasta nuestros días. Tal vez la anécdota de Luculo nunca se habría convertido en dicho si Guevara no la hubiera incluido en su Menosprecio de Corte..., y «el pensamiento es libre» es en gran medida una frase hecha, porque Shakespeare se hizo eco en La tempestad de las palabras de Cicerón. Sin duda, los hermosos versos de J. Chénier en su Tiberio ${ }^{44}$ han contribuido decisivamente a que la expresión «brillar por su ausencia» sea tan común en francés, castellano y otras lenguas de nuestro entorno. Y si la frase «subirse a las barbas» ha calado en la lengua coloquial es debido también a que tocar la barba a alguien fue considerado durante siglos una grave ofensa ${ }^{45}$. Es probable que la divulgación de la frase del emperador Tito «amigos, he perdido el día», pronunciada tras una jornada en la que no había hecho a nadie ningún favor, esté relacionada con su aparición en el libreto de Pietro Metastasio ${ }^{46}$ (La clemenza de Tito), que sirvió a Mozart, Gluk y otros grandes músicos para componer óperas de mucho éxito.

También debemos tener en cuenta que muchas de estas expresiones se convirtieron en proverbios ya en la Antigüedad. Más arriba hemos comentado cómo el testimonio de Quintiliano confirma que ya en su tiempo la expresión «esto lo ve hasta un ciego» era coloquial (caecis hoc, ut aiunt, satis clarum est). Plutarco confirma que, al menos, otras dos de las frases que venimos comentando se habían hecho proverbiales en su época. Tras la derrota de Roma frente a los galos, Breno, su caudillo, colocó en la balanza su pesada espada para aumentar el tributo en oro que los romanos debían pagar; Sulpicio, comandante romano, «preguntó qué era aquello» — continúa Plutarco— «y la respuesta fue: “¿Qué otra cosa ha de ser sino ¡ay de los vencidos!”; expresión que quedó después en proverbio ${ }^{47}$. Al narrar en su biografía de César el paso del Rubicón, dice Plutarco:

Finalmente, como si se dejara llevar por un irrefrenable impulso, fuera de todo raciocinio, hacia el futuro, y tras pronunciar esta frase que se ha convertido en preludio común para quienes se arrojan a avatares dificultosos y audaces: «iLa suerte está echada!», se lanzó con resolución a vadear el río ${ }^{48}$.

41 Aurelio Pérez Jiménez (1990): «Plutarco y el humanismo español del Renacimiento», Estudios sobre Plutarco. Obra y tradición (A. Pérez y G. del Cerro eds.) Madrid, pp. 229-247. J. Bergua Cavero, Estudios sobre la tradición de Plutarco en España (siglos XIII-XVII), Universidad de Zaragoza, 1995.

${ }^{42}$ Rosario Delicado (1992): «La tradición directa de Tito Livio en castellano», Helmántica, 43 (1), pp. $105-$ 110. «La historia interna de Tito Livio en castellano» (1994): VII Congreso español de estudios clásicos, III, Madrid, pp. 421-425.

${ }^{43}$ Cf. Vicente Picón, op. cit., págs. 98-102.

44 Vicente Vega cita en su Diccionario ilustrado de frases célebres y citas literarias (Gustavo Gili, Barcelona, 1952, p. 78) los versos de Chenier: «Devant l'urne funèbre on protait ses aieux/ Entre tous les héros qui, présents à nos yeux,/ provoquaient la douleur et la reconnaissance,/ Brutus et Cassius brillaient par leur absence». (acto $1^{\mathrm{o}}$, escena $1^{\mathrm{a}}$ ).

45 Cf. supra, p. 27 y nota 29.

${ }^{46}$ En el primer acto, dice Sesto: «Fingiti in mente eroe piu generoso, e piu clemente. Inútil chiama, perduoto il giorno ei dice, in cui fatto non ha qualcun felice».

${ }^{47}$ Cf. Plutarco, Camilo, 28, 6.

${ }^{48}$ Plutarco, César, 32, 8 (trad. de Emilio Crespo, Barcelona, Bruñera, 1983). 
Naturalmente, estas frases entraron en los repertorios de refranes latinos más antiguos, que seleccionados y coleccionados en época renacentista ${ }^{49}$ fueron muy utilizados por escritores de toda Europa.

Las excelentes cualidades narrativas de los historiadores de Roma y el apoyo de la tradición explican en parte la conservación de estos dichos, pero hay otras razones menos trascendentes y más curiosas que también han tenido su importancia.

\subsection{Paisanaje y nacionalismo}

Parece claro que cuatro de las frases antes citadas están en nuestra lengua porque recuerdan episodios históricos de la Hispania romana. Hasta donde me es posible saber, ninguna de estas frases se pronuncia en las lenguas de nuestro entorno, y su presencia en la nuestra se debe unas veces al paisanaje, el lógico amor por la patria chica y sus gentes, y otras al nacionalismo, la exaltación desmesurada de los valores patrios.

«Roma no paga traidores» es frase utilizada para dejar claro que el traidor no es grato ni siquiera a aquellos que promueven su traición; la frase se atribuye al comandante romano que encabezaba la guerra en Hispania contra los lusitanos. Al parecer, con esas palabras se negó a pagar recompensa alguna a los asesinos de Viriato, tres oficiales de su ejército llamados Audax, Ditalco y Minuro, a los que previamente Roma había impulsado a la conspiración ${ }^{50}$. Viriato es nuestro «otro» caudillo, pues, después de cuarenta años de dictadura, el término ha quedado prácticamente reservado para designar al general Fran$\mathrm{co}^{51}$. En realidad, sólo Viriato parece disputarle ese nombre, y ello gracias al nacionalismo, que en las enciclopedias de la época franquista, y probablemente antes, hacía a Viriato un caudillo defensor de la libertad de su nación frente al opresor romano. Este hecho ha contribuido decisivamente a que la frase se haya convertido en proverbio.

Otra expresión muy utilizada es «hacer o practicar una defensa numantina». Se emplea con frecuencia en los debates parlamentarios y en los comentarios deportivos. Con doble sentido: negativo, para criticar a la persona que se enroca en posiciones inamovibles que no tienen salida; positivo, para elogiar a alguien que defiende con resolución sus principios o resultados contra los ataques del adversario. La frase, evidentemente, hace referencia a la heroica resistencia de la ciudad de Numancia frente a las tropas romanas en las guerras celtibero-lusitanas (143-133 a. C.). El asedio de la ciudad, que tuvo tintes particularmente dramáticos en sus últimos once meses, se exaltó en diferentes épocas de nuestra historia como ejemplo del valor y la capacidad de resistencia de la nación española. El hecho de que el ejército romano estuviera comandado por Escipión Emiliano ha contribuido también a engrandecer la leyenda, pues este Escipión es ciertamente un personaje paradójico, especialista en destruir ciudades — antes había asolado Cartago— y patrono del círculo literario de mayor influencia cultural en la República romana.

\footnotetext{
49 Recordemos aquí la importancia de los Adagia de Erasmo.

${ }^{50}$ Cf. Apiano, Iberia, LXXIV (311-314). Epitome de Oxyrhymchos, 1, 201-202: interfectores Viriathi urbe pulsi sunt, praemium negatum. Valerio Máximo, 9, 6, 4.

${ }^{51}$ El nombre del líder forma parte de la simbología fascista: Mussolini fue llamado duce, (dux, guía). Franco caudillo (capitellus, cabecilla) y Hitler, Führer, correspondencia alemana del término latino dux.
} 
El dicho «tener un hambre calagurritana» evoca el sombrío episodio de las guerras sertorianas (82-72 a. C.), en el que los calagurritanos, fieles a la causa del rebelde Sertorio, resistieron a las tropas pompeyanas, comandadas por Afranio, hasta la destrucción de la ciudad. En este caso, sin embargo, no ha habido exaltación nacionalista, pues, según las fuentes, los habitantes de Calagurris practicaron en los últimos momentos del asedio actos de canibalismo, lo que ha empañado la heroica resistencia de la ciudad. Salustio cuenta que incluso salaron los cadáveres para que durasen más. El episodio es comentado también por Juvenal en su sátira $\mathrm{XV}^{52}$. En esta ocasión el hecho de que el proverbio haga alusión a una localidad hispana ha contribuido a su aparición en el lenguaje coloquial, pero mucho más el humor negro implícito en la frase: tener un hambre calagurritana es tener tal apetito que uno sería capaz de comerse a sus congéneres. Más adelante comentaremos la ironía y el contraste en algunos de estos dichos.

En nuestro país, ser una sabio es «ser un Séneca». El dicho suele utilizarse con cierta ironía, pero a veces también con admiración por quien así es interpelado. En esta preeminencia de Séneca sobre otros sabios de la Antigüedad creo que ha sido fundamental una famosa serie de televisión de los años sesenta, cuyo protagonista, un sensato caballero andaluz de pueblo, era apodado con tal nombre por sus paisanos. La serie, escrita por José María Pemán, tuvo un enorme éxito, y la utilización por parte del autor del nombre del filósofo revela que ya antes Séneca gozaba del predicamento que el dicho atestigua. Sin duda, el paisanaje también ha contribuido al éxito; Séneca era cordobés y estas cosas, sobre todo en tiempos de nacionalismo, cuentan mucho.

\subsection{Homofonía y sonoridad}

En algunos casos la fonética también ha facilitado la conservación de estas expresiones. Unas veces, por el parecido fónico de la palabra clave con otras de semántica parecida, y otras, por la sonoridad de la frase. Por ejemplo, «estar en el Aventino» puede ser entendido por personas que desconocen la Historia de Roma como «estar en el aventadero», el lugar apartado de la casa donde se aventaba el grano; también podía entenderse que quien «se iba al Aventino» estaba aventado, es decir, atolondrado. En «pasar por las horcas caudinas» el hablante medio desconoce que Furcae Caudinae era el nombre de dos desfiladeros próximos a la ciudad de Caudium; es lógico suponer que el término horca se entienda como la soga utilizada para ajusticiar y, desde luego, pasar por una horca Caudina o «Claudina» —o como se llamase- era algo terrible. Creo que el parecido fónico de pírrico con otros adjetivos como raquítico o birrioso ha contribuido al mantenimiento de la expresión en nuestra habla con un sentido equivocado, pues se suele utilizar como si pírrica fuera una victoria fea o escasa, cuando en realidad es una victoria difícil y que no comporta buenos resultados. Seguramente, la proximidad fónica entre el nombre de Tiberio y la palabra «laberinto» ha ayudado a que dos dichos de significación parecida, «se armó un Tiberio» y «se formó un laberinto», se hayan introducido en el habla popular, que, si ha elegido al emperador Heliogábalo cómo comilón prototípico, es tan-

\footnotetext{
52 Sobre este tema, cf. José Luis Ramírez Sádaba (1985): «Limitaciones inherentes a las fuentes literarias: consecuencias de las guerra sertoriana para Calagurris», Gerion, 3, pp. 231-243.
} 
to por lo que de él nos cuentan sus biógrafos como las resonancias de su nombre, que parece emparentado con palabras como «tragaldabas», «goloso», «glotón», etc.. No podemos olvidar tampoco la semejanza de Heliogábalo con sus competidores en semejante función, los personajes de Rabelais, Gargantúa y Pantagruel.

También la extraña sonoridad de palabras como «calagurritana»o «Luculo» ha podido ser decisiva en el uso de los dichos más arriba comentados. E, igualmente, en la frase de César «vine, vi, vencí» la repetición de los verbos es fundamental, tal y como apunta Plutarco ${ }^{53}$ : «en latín, estas palabras (veni, vidi, vici), al tener la misma terminación, tienen gran expresividad en su concisión». Podríamos añadir que la aliteración del fonema inicial y la secuencia de tres bisílabos han contribuido también a la conservación del dicho. Solemos emplear la frase cuando queremos indicar rapidez y eficacia en la ejecución de un asunto, y la métrica aporta también esa sensación de rapidez.

\subsection{Ironía y contraste}

La ironía, como ocurre con la sonoridad, es uno de los elementos frecuentes en la fraseología ${ }^{54}$. En las expresiones que analizamos también tiene una presencia importante, con perspectivas tan diferentes como las implícitas en el propio término, desde el contraste burlesco a la hipérbole.

Llama la atención la aplicación a pequeños episodios de la vida corriente de las trágicas hazañas de los romanos. La radical retirada de la plebe romana al Mons Sacrum sirve para ridiculizar el enfado infantil de alguien que se «amula» 0 «mosquea». La terrible humillación en las Horcas caudinas, un suceso nunca digerido por la nación romana, suele recordarse ante ligeros contratiempos de la vida corriente que tuercen en escasa medida nuestra voluntad. Una simple regañina se equipara con las filípicas que costaron la vida a Cicerón. Un buen apetito se iguala con el hambre de los calagurritanos, forzados al canibalismo. O, en fin, un simple barullo se utiliza para evocar las terribles persecuciones del emperador Tiberio.

La expresión «brillar por su ausencia» se emplea en numerosas ocasiones con ironía. Con un sentido diferente al que tenía la frase de Tácito cuando afirmó que la ausencia de las imágenes de Bruto y Casio en el funeral de Junia, hermana del primero y esposa del segundo, les hizo brillar más que si hubieran estado presentes ${ }^{55}$. En la actualidad se emplea frecuentemente para denunciar la ausencia de alguien en un momento en que debería haber estado presente.

\subsection{Tópicos en los medios de comunicación}

La frecuencia de algunas de estas expresiones en nuestra conversación tiene una estrecha conexión con el uso, a veces abuso, que de ellas hacen algunos periodistas, parti-

${ }^{53}$ Cf. Plutarco, César, 50,4.

${ }^{54}$ Sobre el particular, cf. Joaquín García-Medall (ed.), Fraseología e ironía. Descripción y contraste, Lugo, Axac, 2006.

${ }^{55}$ C. Tácito, An. III 76. 
cularmente en temas deportivos o políticos, en los que está presente la confrontación. El marco bélico y militar en que se usaron muchas de ellas es muy útil para esquematizar hiperbólicamente el resultado del agón pacífico y cívico que hay detrás de los encuentros deportivos y los debates políticos. Sin duda, a ello deben su espléndida salud dichos como «victoria pírrica», «defensa numantina», «la suerte está echada», «hay que morir de pie», etc.

Digamos, para concluir, que bienvenidos sean tales tópicos si ellos mantienen vivo el recuerdo del Mundo Clásico, y ojalá este trabajo, junto con el que ya preparamos sobre las costumbres de los romanos en el habla coloquial, puedan contribuir, si quiera modestamente, al mismo propósito. 